\title{
GAYA BAHASA PERUMPAMAAN DALAM NOVEL \\ CINTA DI DALAM GELAS KARYA ANDREA HIRATA
}

\section{THE STYLE OF FIGURATIVE LANGUAGE IN THE NOVEL LOVE IN THE GLASS BY ANDREA HIRATA}

\author{
Agus Yulianto \\ Balai Bahasa Provinsi Kalimantan Selatan \\ Jalan A. Yani, Km 32,2 Loktabat, Banjarbaru, Kalimantan Selatan \\ Telp: 0511-4772641, Pos-el: agusb.indo@gmail.com
}

\begin{abstract}
Abstrak
Tujuan penelitian ini adalah untuk mendeskripsikan bentuk-bentuk gaya bahasa perumpamaan yang terdapat dalam novel Cinta di dalam Gelas serta mengungkapkan makna yang dikandungnya. Penelitian ini menggunakan metode deskriptif kualitatif dengan teknik catat, klasifikasi, dan analisis. Selain itu, metode analisis konten juga digunakan untuk menelaah isi teks untuk mengetahui penggambaran pemakaian gaya bahasa perumpamaan dalam novel. Berdasarkan hasil analisis dapat diketahui bahwa gaya bahasa perumpamaan yang dipakai pengarang meliputi pemakaian kata seperti, bak, macam, dan ibarat.
\end{abstract}

Kata kunci: novel, gaya bahasa, perumpamaan

\begin{abstract}
The purpose of this study is to know how the forms of style figurative language in the novel Love in the Glass and the meaning it contains. Thus the problem in this study is how the forms of style figurative language in the novel Love in the Glass and what the meaning it contains. This research uses descriptive qualitative method with technique of record, classification and analysis. In addition, content analysis methods are also used to examine the contents of the text to know the description of the use of parable style in the novel. Based on the results of the analysis can be seen that the parable style of language used by the author includes the use of words such as, tub, kind, and like.
\end{abstract}

Keywords: novel, language style, pigurative

\section{Pendahuluan}

Karya sastra berbentuk prosa, seperti novel, tentu tidak akan lepas dari pemakaianbahasa. Bahasa yang dipakai oleh seorang pengarang dalam menciptakan karya sastra harus mengandung nilai estetik. Oleh sebab itu, tidak heran bila Nurgiyantoro (2002:272) menyatakan bahwa bahasa dalam seni sastra ini dapat disamakan dengan cat warna. Keduanya merupakan unsur bahan, alat, dan sarana yang mengandung nilai lebih untuk dijadikan sebuah karya. Sebagai salah satu unsur terpenting tersebut, bahasa berperan sebagai sarana pengungkapan dan penyampaian pesan dalam sastra. Bahasa dalam karya sastra mengandung unsur keindahan. Keindahan adalah aspek dari estetika. Lebih jauh, Zulfahnur dkk. (1996:9) menyatakan bahwa sastra merupakan karya seni yang berunsur keindahan. Keindahan dalam karya seni sastra dibangun oleh seni kata, dan seni kata atau seni bahasa tersebut berupa kata-kata yang indah yang terwujud dari ekspresi jiwa.

Salah satu novelis saat ini yang sangat piawai dalam merangkai kata-kata dalam karya sastranya adalah Andrea Hirata. Oleh sebab itu, tidak heran bila Andrea Hirata mendapat julukan "maestro kata-kata". Salah satu perangkat yang digunakan dalam menciptakan nilai estetik sastra tersebut adalah adanya penggunaan gaya bahasa. Hal tersebut 
sesuai dengan pendapat Aminuddin (2001:5) yang menyatakan bahwa fungsi gaya bahasa adalah (1) memaparkan gagasan secara lebih hidup dan menarik, (2) menggambarkan suasana secara lebih hidup dan menarik, (3) menekankan ataupun menyanggahkan suatu gagasan, dan (4) menyampaikan gagasan secara tidak langsung. Gaya bahasa itu sendiri terdiri atas empat jenis, yaitu gaya bahasa perulangan, perbandingan, pertautan, dan pertentangan.

Salah satu novel karya Andrea Hirata yang berjudul Cinta di dalam Gelas yang diterbitkan Bentang Pustaka pada tahun 2011 banyak menggunakan gaya bahasa, terutama gaya bahasa perumpamaan. Gaya bahasa perumpumaan, menurut Tarigan (2011:118), adalah gaya bahasa yang membandingkan dua hal yang pada hakikatnya berlainan dan yang sengaja kita anggap sama. Perbandingan itu secara eksplisit dijelaskan oleh pemakaian kata seperti, ibarat, umpama, bak, laksana, dan sejenisnya.

Pemakaian gaya bahasa perumpamaan dalam sebuah karya sastra tentu mengandung makna tertentu. Oleh sebab itu, tujuan dalam penelitian ini adalah mendeskripsikan bentukbentuk gaya bahasa perumpamaan yang terdapat dalam novel Cinta di dalam Gelas serta mengungkapkan makna yang dikandungnya. Dengan demikian, masalah dalam penelitian ini adalah bagaimanakah deskripsi bentuk-bentuk gaya bahasa perumpamaan yang terdapat dalam novel Cinta di dalam Gelas serta apa makna yang dikandungnya?.

Menurut Tarigan (2011:164-165),novel atau sering disebut sebagai roman adalah suatu cerita prosa yang fiktif dalam panjang yang tertentu yang melukiskan para tokoh, gerak, serta adegan nyata yang representatif dalam suatu alur atau suatu keadaan yang agak kacau atau kusut. Novel mempunyai ciri bergantung pada tokoh, menyajikan lebih dari satu impresi, menyajikan lebih dari satu efek, menyajikan lebih dari satu emosi.

Menurut Sudjiman (1998:53), bahwa novel adalah prosa rekaan yang menyuguhkan tokoh dan menampilkan serangkaian peristiwa serta latar secara tersusun. Hendy (1993: 225) mengemukakan bahwa novel merupakan prosa yang terdiri dari serangkaian peristiwa dan latar. Hendy juga menyatakan bahwa novel tidaklah sama dengan roman. Sebagai karya sastra yang termasuk ke dalam karya sastra modern, penyajian cerita dalam novel dirasa lebih baik.

Gaya bahasa menurut Harimurti (dalam Pradopo, 2005:265) adalah pemanfaatan atas kekayaan bahasa seseorang dalam bertutur atau menulis, lebih khusus adalah pemakaian ragam bahasa tertentu untuk memperoleh efek tertentu. Efek yang dimaksud dalam hal ini adalah efek estetis yang menghasilkan nilai seni.Menurut Achmadi (1988:155-156), gaya bahasa adalah kualitas visi, pandangan seseorang, karena merefleksikan cara seorang pengarang memilih dan meletakkan kata-kata dan kalimat-kalimat dalam mekanik karangannya. Gaya bahasa menciptakan keadaan perasaan hati tertentu, misalnya kesan baik ataupun buruk, senang, tidak enak dan sebagainya yang diterima pikiran dan perasaan karena pelukisan tempat, benda-benda, suatu keadaan atau kondisi tertentu.

Definisi gaya bahasa menurut Minderop (2005:51) adalah bahasa yang bermula dari bahasa yang biasa digunakan dalam gaya tradisional dan literal untuk menjelaskan orang atau objek. Dengan menggunakan gaya bahasa, pemaparan imajinatif menjadi lebih segar dan berkesan. Gaya bahasa mencakup: arti kata, citra, perumpamaan, serta simbol dan alegori. Arti kata mencakup, antara lain: arti denotatif dan konotatif, alusi, parodi dan sebagainya; sedangkan perumpamaan mencakup simile, metafora, dan personifikasi.

Moeliono (1989:175) membedakan gaya bahasa menjadi tiga, yakni (1) perbandingan, yang meliputi perumpamaan metafora, dan penginsanan; (2) pertentangan, yang meliputi hiperbola, litotes, dan ironi; dan (3) pertautan, yang meliputi metonomia, sinekdoke, kilatan, dan eufemisme.

Gaya bahasa perumpamaan menurut Tarigan (2011:118) adalah gaya bahasa yang membandingkan dua hal yang pada hakikatnya berlainan dan yang sengaja kita anggap sama. Perbandingan itu secara eksplisit dijelaskan 
oleh pemakaian kata seperti, ibarat, umpama, bak, laksana, dan sejenisnya.

Menurut Kamus Besar Bahasa Indonesia (2013:703), makna adalah maksud pembicara atau penulis; pengertian yang diberikan kepada suatu bentuk kebahasaan. Makna itu sendiri terbagi menjadi beberapa makna yang di antaranya ialah makna konotasi dan makna denotasi.

Makna konotatif menurut Zainuddin (1991:84) adalah makna kata atau sekelompok kata yang didasarkan atas perasaan atau pikiran yang ditimbulkan oleh pembicara atau penulis kepada pendengar atau pembaca. Sifat makna konotatif sangat subjektif karena makna yang dikandung dalam kata atau kelompok kata bersifat tambahan. Contoh makna konotatif sebagai berikut.

a.Wanita itu manis.

Kata manis pada kalimat di atas bermakna konotatif elok.

b.Dia adalah bunga desa.

Frase bunga desa pada kalimat di atas bermakna konotatif gadis yang tercantik.

c.Jam tanganmu manis.

Kata manis pada kalimat di atas bermakna konotatif mungil bentuknya.

Makna denotatif menurut Zainuddin (1991:85) adalah makna kata atau kelompok kata yang didasarkan atas pertunjukan yang lugas pada sesuatu di luar bahasa atau yang didasarkan atau konvensi tertentu. Sifat makna denotatif adalah objektif karena makna yang dikandung dalam kata atau kelompok kata sifatnya pasti atau sudah tertentu maknanya. Contoh makna denotatif sebagai berikut.

a.daun, artinya bagian tanaman yang tumbuh berhelai-helai pada ranting sebagai alat bernapas dan mengolah zat makanan.

b.bulan, artinya benda langit yang mengitari bumi, tampak terang pada malam hari.

c.mawar, artinya nama bunga.

Makna kata yang terdapat dalam gaya bahasa perumpamaan yang terdapat dalam novel Cinta di dalam Gelas ini meliputi makna denotatif dan konotatif.

\section{Metode}

Penelitian ini merupakan penelitian kualitatif dengan menggunakan metode deskriptif. Metode kualitatif adalah metode yang paling cocok untuk fenomena sastra (Endraswara, 2011:5). Sesuai dengan pendapat Bogdan dan Taylor (dalam Moleong, 2007:4), penelitian kualitatif adalah prosedur penelitian yang menghasilkan data deskriptif berupa kata-kata tertulis atau lisan tentang orang-orang dan perilaku yang dapat diamati. Metode deskriptif adalah metode yang dilakukan dengan tidak menggunakan angka-angka, tetapi menggunakan penghayatan terhadap interaksi antarkonsep yang sedang dikaji secara empiris (Semi, 1993:23). Selain itu, metode analisis konten juga digunakan untuk menelaah isi teks untuk mengetahui penggambaran pemakaian gaya bahasa perumpamaan dalam novel. Analisis konten adalah strategi untuk menangkap pesan karya sastra (Endraswara, 2011:161).

Teknik pengumpulan data dilakukan dengan menggunakan teknik catat, yaitu dengan membaca isi novel secara keseluruhan kemudian mencatat kalimat-kalimat atau paragraf yang mengandung gaya bahasa perumpamaan. Data-data tersebut kemudian dianalisis untuk mengetahui makna gaya bahasa yang dikandungnya.

\section{Hasil dan Pembahasan}

Bentuk-bentuk gaya bahasa perumpamaan beserta maknanya yang terdapat dalam novel Cinta di dalam Gelas sebagai berikut.

1. "Kedua mata itu berbicara lebih lancang dari mulutnya, namun menyimpan rahasia yang dalam, seperti ada cinta yang juga terluka, hidup yang tersia-sia, dan dendam yang membara." (Hirata:14)

Makna pemakaian gaya bahasa sebagai berikut. Penggambaran atau deskripsi ini adalah mengenai seorang preman yang bernama Preman Cebol yang berbicara melalui sorot matanya. Mata adalah jendela jiwa. Sorot mata Preman Cebol sarat dengan rahasia. Akan tetapi, sorot mata itu mengandung luka 
yang dapat diumpamakan dengan sesuatu yang menyakitkan dan melukai jiwa.

2. Penampilannya semakin ganjil karena bahunya timpang. Konon karena ketika kecil ia membanting tulang seperti budak belian di bawah perintah pamannya yang kejam. (Hirata:15)

Makna pemakaian gaya bahasa sebagai berikut. Penggambaran atau deskripsi ini masih mengenai diri Preman Cebol. Cacat yang terjadi pada bahunya tidak lain disebabkan oleh pola kerjanya yang terlalu keras. Saking kerasnya kerja yang dilakukan oleh Preman Cebol dapat dibandingkan dengan kerja kerasnya para budak belian. Para budak belian dibentuk tidak lain hanyalah untuk diperas tenaganya sebesar-besarnya. Demikian juga Preman Cebol yang akhirnya mengakibatkan bahunya menjadi cacat.

3. Tato penjara, centang perenang di kedua lengannya. Tato di tangan kanan, seperti almanak, menampakkan hari-hari agung yang ia lalui di bawah kurungan. (Hirata: 15)

Makna pemakaian gaya bahasa sebagai berikut. Pengambaran atau deskripsi ini pun masih mengenai Preman Cebol. Untuk menunjukkan eksistensi dirinya sebagai seorang preman, salah satunya ditunjukkan dengan banyaknya tato yang terdapat dalam tubuhnya. Bahkan, tato yang berada di tangan kanan Preman Cebol dapat diumpamakan sebagai simbol kumpulan hari-hari selama dirinya berada dalam penjara.

4. Benu menjadi kuli, gagap, dan sedikit gila. Tapi pukalannya sendiri, jangan sembarangan. Beras 200 kilogram digantung bergoyang seperti penyanyi dangdut jika dihantamnya. (Hirata:16)

Makna pemakaian gaya bahasa sebagai berikut. Benu adalah salah satu anak buah preman cebol. Kekuatan pukulannya sungguh luar biasa. Jika beras seberat $200 \mathrm{~kg}$ digantung kemudian dipukulnya, beras itu akan bergoyang. Goyangannya sama bila dibandingkan dengan penyanyi dangdut. Penyanyi dangdut adalah seorang penyanyi yang memiliki goyangan yang sangat lincah. Dengan demikian, perbandingan tersebut menjelaskan bahwa betapa kuatnya tenaga pukulan Benu.

5. Lelaki Melayu dengan kopi, sisa kebanggaan, dan catur, seperti lelaki Melayu dengan pantunnya, seperti lelaki suku bersarung dengan sarungnya, seperti lelaki Khek dengan sempoanya. (Hirata:30)

Lelaki Melayu sangat suka dengan kopi dan catur. Oleh sebab itu, tidak heran bila kesukaan itu disamakan dengan lelaki Melayu dengan pantunnya, lelaki suku bersarung dengan sarungnya dan lelaki (Cina) Khek dengan sempoanya. Hal itu menjelaskan betapa keterikatan lelaki Melayu dengan kopi dan catur begitu sangat erat.

6. Maka hidup kami seperti main petak umpat dengan Tuhan. Kami tidak menabur sehingga benda itu ada di situ, dan kami tak perlu merawatnya sehingga ia beranak pinak. (Hirata:59)

Makna pemakaian gaya bahasa sebagai berikut. Masyarakat Melayu yang berprofesi sebagai penambang timah adalah orang-orang yang sangat bergantung pada keberuntungan proses pencarian terhadap timah itu sendiri. Mereka mencari timah secara untunguntungan. Oleh sebab itu, profesi pencarian timah ini sangat bergantung pada asas keberuntungan. Tidak heran bila para pencari timah ini membandingkan diri mereka sedang main petak umpet dengan rezeki yang Tuhan sediakan untuk mereka.

7. Seperti musim, hati Sersan Kepala Zainuddin sedang kemarau. Kepala polisi itu dongkol benar lantaran persis seperti musim pula maling sepeda kambuh lagi. (Hirata: 68)

Musim di Indonesia hanya terdiri atas musim kemarau dan musim hujan. Musim kemarau berarti musim panas, musim 
kekeringan. Hati atau perasaan Sersan Kepala Zainuddin diumpamakan seperti musim kemarau memiliki arti bila perasaan Sersan kepala sedang marah. Hal itu disebabkan oleh maling sepeda mulai beraksi kembali di kampungnya.

8. Namanya pun seperti nama musala, tapi kelakuannya macam iblis (Hirata:71)

Musala pasti memiliki nama-nama yang baik. Bromocorah yang sering melakukan pencurian sepeda bernama Muhlasin. Nama Muhlasin diumpamakan nama musala yang pasti berkonotasi baik. Akan tetapi, sayang sekali pekerjaannya adalah mencuri sepeda.

9. "Mengapa rupamu seperti dilanda angin puting beliung begitu? Kita ini berada dalam usaha keramahtamahan? Penampilan sangat penting!" (Hirata:86)

Akibat dilanda puting beliung pasti akan berantakan atau hancur tidak karuan. Ekspresi wajah yang diumpamakan terkena puting beliung adalah ekspresi wajah yang pasti tidak enak untuk di pandang atau dilihat. Oleh sebab itulah, Paman yang berprofesi sebagai penjual kopi seduh memarahi pelayannya agar tidak menampakkan wajah atau ekspresi yang kurang enak untuk dilihat.

10. Esoknya, gawat, berita soal Maryamah menyebar cepat seperti sampar ayam. (Hirata: 93)

Maksud sampar ayam adalah penyakit menular yang terdapat pada ayam. Penyakit ini biasanya begitu cepat menyebar. Oleh sebab itu, berita mengenai Maryamah yang ingin ikut perlombaan catur tujuh belasan di kampungnya diumpamakan sampar ayam yang berarti begitu cepat penyebarannya. Hal itu juga disebabkan Maryamah adalah satusatunya wanita yang ikut dalam perlombaan catur tersebut.

Gramatika, Volume VI, Nomor 1, Januari-Juni 2018
11. Akibat sikap Paman yang melantur, Selomot dan Mitoha kembali bertengkar seperti pertengkaran para tukang minyak tanah di pinggir jalan. (Hirata: 107)

Pertengkaran yang terjadi antara Selomot dan Mitoha diumpamakan pertengkaran para tukang minyak tanah, yang berarti pertengkaran itu sangat hebat. Hal itu disebabkan tukang minyak tanah adalah orang yang berteriak-teriak ketika menjajakan dagangannya. Dengan demikian, dapat dibayangkan ketika para tukang minyak tanah sedang bertengkar.

12. Mulanya aspal, terus batu merah, lalu jalan pasir yang meliuk-liuk sesuka hatinya seperti ular manau. (Hirata:109)

Ular adalah binatang yang meliuk-liukkan dirinya saat berjalan. Oleh sebab itu, mengumpamakan jalan seperti jalan ular berarti bahwa jalan tersebut memang penuh dengan liukan dan belokan.

13. Pertandingan baru berjalan beberapa langkah, namun Aziz langsung bingung melihat perwira-perwira Maryamah mengamuk seperti angin puting beliung. (Hirata: 142)

Angin puting beliung adalah fenomena alam yang memiliki daya rusak luar biasa. Langkah-langkah perwira catur Maryamah yang diumpakan angin puting beliung berarti langkah-langkah perwira catur Maryamah tersebut memiliki daya rusak luar biasa terhadap pertahanan catur Aziz.

14. Sebaliknya, didekat c6 itu, menteri Maryamah menganga bak ular boa. (Hirata: 153)

Menteri catur Maryamah sudah berada dalam posisi menskakmat rajanya Maksum, lawan catur Maryamah. Pemakaian kata perumpamaan menganga bak ular boa mempunyai arti bila menteri catur Maryamah sudah siap-siap menskakmat raja catur Maksum. 
15. "Itulah catur yang sebenarnya, Boi! Kalian pikir main catur macam main ular tangga! Rasakan itu!" (Hirata: 157)

Permainan ular tangga adalah sebuah permainan yang tidak didasarkan pada proses berpikir, melainkan hanya keberuntungan. Hal itu disebabkan oleh permainan ular tangga hanya mengocok bola dadu dan berharap angka yang keluar sesuai dengan angka yang diinginkan untuk melangkahkan bidak di dalam kotak ular tangga. Permainan Catur sangat berbeda dengan permaianan ular tangga. Dalam permaianan catur diperlukan proses berpikir yang rumit hanya untuk menggerakkan sebuah bidak catur. Hal itu disebabkan melalui langkah-langkah caturyang tepatlah permainan dapat dimenangi.Tidak sembarang orang dapat bermain dan memenangi sebuah permainan catur. Akan tetapi, dapat dipastikan hampir sebagian besar orang dapat bermain permainan ular tangga. Dengan demikian, membandingkan antara permainan catur dan ular tangga hanya di maksudkan betapa rumit sebenarnya permainan catur tersebut.

16. Kerap, kode-kode itu kuanggap bak potongan kunci yang diperlukan Indiana Jones untuk membuka peti harta karun. (Hirata: 164)

Kode-kode catur yang diterima ikal dari grand master catur Ninochka Stronovsky sesunguhnya agak sulit untuk dipahami. Oleh sebab itu, kode-kode catur itu diumpakan seperti potongan kunci yang diperlukan Indiana Jones untuk membuka peti harta karun.

17. Pernah pula ada satu masa ketika kopi dianggap seperti rokok sehingga perempuan yang minum kopi dianggap tidak patut. (Hirata:177)

Kopi adalah minuman yang dianggap khas minuman untuk laki-laki. Bahkan, saking khasnya minuman laki-laki ini ada yang mengumpamakan seperti rokok yang juga khas kebiasaan laki-laki. Sangat jarang ditemui ada wanita yang merokok. Demikian juga dengan mengopi walaupun saat ini tidak susah mencari wanita yang merokok ataupun minum kopi.

18. Maka, kopi miskin adalah kopi pahit, sepahit-pahitnya, seperti nasib pembelinya. (Hirata:177)

Kopi miskin adalah kopi yang tidak memakai gula. Hal itu disebabkan harga gula relatif mahal, sedangkan penikmat kopi miskin rata-rata adalah orang miskin. Pengumpamaan kopi miskin dengan nasib pembelinya yang sama-sama pahit terasa begitu sesuai.

19. Kumasukkan bubuk kopi yang halus ke dalamnya, ia mulai berputar. Suara barisan string tadi meningkat menjadi berdesing bak pesawat terbang bermesin Rollss-Royce yang mau tinggal landas. (Hirata: 180)

Suara barisan string adalah suara yang dihasilkan oleh blender penghalus kopi. Suara mesin blender yang keluar tersebut sesuai dengan tingkatan kecepatan mesin itu sendiri. Makin cepat mesin blender tersebut berputar, makin berdesing suaranya. Pengumpamaan suara mesin blender dengan suara pesawat terbang bermesin Rolls-Royce bermakna bila suara mesin blender tersebut sangat terakselerasi dan memiliki kekuatan.

20. Akhirnya, saat dimatikan, bunyi blender itu kembali melalui beberapa tahap, dari mendesah menjadi berdenging, lalu lambat laun mendesau, lembut sekali, bak angin pagi musim selatan. (Hirata: 180)

Angin pagi musim Selatan adalah angin pagi yang sangat lembut dan membuai. Kelembutan angin pagi musim Selatan tersebut diumpamakan dengan suara mesin blender penghalus kopi saat mulai berhenti. Hal itu berarti bahwa suara mesin blender penghancur kopi saat mulai berhenti demikian lembut dan membuai. 
21. Maka, meraung-raunglah blender itu seperti hewan kena siksa. Aku tak sampai hati melihatnya. (Hirata:183)

Blender penghalus kopi memiliki cara pemakaian. Salah satunya kopi yang diblender sebelumnya harus dihaluskan terlebih dahulu agar kerja mesin tidak terlalu berat. Akan tetapi, Paman memasukkan biji-biji kopi secara sembarangan saja. Akibatnya, mesin blender meraung-raung karena kerja mesin menjadi berat. Pengumpamaan seperti hewan kena siksa menjelaskan betapa berat kerja mesin blender itu.

22. Usai tarawih, Paman pulang dengan langkah terkangkang-kangkang seperti gorila. (Hirata: 209)

Gorila adalah hewan yang apabila berjalan memiliki gestur tubuh seperti terkangkang-kangkang dan hal itu sudah menjadi gerakan tubuh yang semestinya. Mengumpamakan langkah Paman seperti Gorila dapat dipastikan langkah Paman pasti sangat terkangkang disebabkan sakit yang dideritanya.

23. Perhitungan si pintar Lintang tak meleset. Satu rombongan besar sekondan klub Di Timoer Matahari datang ke warung kopi seperti segerombolan mafia. (Hirata: 220)

Mafia adalah organisasi kejahatan yang ada di Italia. Mengumpamakan klub Di Timoer Matahari dengan Mafia memberi kesan bahwa pecatur-pecatur yang ada di klub tersebut berperan sebagai tokoh-tokoh antagonis.

24. Kemenangan Matarom atas Firman Murtado melejitkannya ke final, dan bertenggerlah dia di sana, macam burung pemakan bangkai menunggu korban. (Hirata: 237)

Matarom sudah dipastikan masuk ke final. Matarom juga diprediksi memenangkan perlombaan catur tahun ini. Oleh sebab itu, para pendukungnya dan masyarakat menganggap Matarom berada di atas angin dan akan membantai siapa saja lawan yang berhasil masuk final. Dengan demikian, tidak aneh bila Matarom diumpamakan burung pemakan bangkai yang sedang menunggu korban.

25. Mereka ketakutan seperti kucing dikepung anjing (Hirata: 243)

Pelayan-pelayan warung kopi Paman sangat takut dengan Paman. Ketakutan itu diumpakan dengan kucing yang sedang dikepung Anjing. Seekor kucing bila berhadapan dengan seekor anjing saja sudah ketakutan apalagi bila dikepung oleh sekumpulan anjing tentu tingkat ketakutannya makin menjadi-jadi. Demikian perumpaman ketakutan para pelayan warung kopi terhadap Paman.

\section{Sekak stir dari Overste bak anak-anak panah yang berdesing di dekatnya. (Hirata: 257)}

Gaya bercatur Overste bersifat menyerang. Oleh sebab itu, Overste melakukan sekak setir berkali-kali. Sekak setir Overste ini diumpamakan desingan anak-anak panah yang berseliweran ke arah Maryamah.

\section{Orang-orang yang selama ini selalu menganggap Maryamah melaju karena berjumpa dengan pecatur kelas tiga, seperti kena siram dengan kopi panas mukanya.(Hirata: 259)}

Pada awalnya orang-orang menganggap remeh kemampuan Maryamah dalam bermain catur. Mereka beranggapan kemenangan Maryamah atas beberapa pemain catur disebabkan oleh lawan Maryamah tersebut lemah. Akan tetapi, setelah Maryamah berhasil mengalahkan pemain catur andal baru mereka menyadari kemampuan Maryamah tersebut. Oleh sebab itu, mereka diumpamakan kena siram dengan kopi panas mukanya disebabkan rasa malu yang dideritanya.

28. Bagi orang-orang tertentu, Maryamah dan Selomot misalnya, yang selama 
hidupnya selalu kalah, papan catur bak pusat putaran nasib. (Hirata: 285).

Maryamah dan Selomot adalah orangorang marjinal yang selalu terpinggirkan. Cara menunjukkan eksistensi mereka di tengahtengah masyarakatnya salah satunya adalah dengan mengikuti perlombaan catur yang begitu bergengsi di kampungnya. Oleh sebab itu, di atas papan catur itulah seakan-akan nasib mereka, gengsi mereka, keberadaan mereka dipertaruhkan. Apabila Maryamah menang dalam perlombaan catur, dengan sendirinya harkat dan derajatnya akan naik di mata masyarakat.

29. Lalu aku berpikir, seumpama catur, hidup sedikit banyak bak reaksi atas pilihan sulit yang silih berganti memfait accompli manusia, dan alasan selalu lebih mudah dilupakan ketimbang akibat. (Hirata:287).

Pilihan-pilihan langkah dalam bercatur akan menentukan menang kalah seseorang. Demikian juga dengan kehidupan manusia. Oleh sebab itu, perumpamaan pilihan langkah catur dengan pilihan langkah-langkah dalam kehidupan nyata terasa sangat sesuai.

30. Katanya, di mana pun ia tak pernah melihat orang menonton catur seperti menonton sepak bola, ribut. (Hirata: 293).

Pertandingan sepak bola biasanya ditonton oleh orang banyak dan menimbulkan keributan, sedangkan pertandingan catur biasanya hanya sedikit penontonnya dan biasanya tenang. Akan tetapi, penonton pertandingan catur tujuh belasan di kampung Ikal tidak demikian. Suasana penonton catur di kampung Ikal diumpamakan seperti orang menonton pertandingan sepak bola yang ramai dan ribut. Perbandingan itu menunjukkan betapa ramai dan ributnya para penonton catur saat perlombaan tujuh belasan di kampung Ikal.

31. Dua langkah berikutnya, raja Maryamah terapung-apung seperti capung yang tak sadar akan disambar prenjak. (Hirata: 298).

Pertahanan catur yang dimainkan Maryamah sudah porak-poranda. Oleh sebab itu, raja Maryamah dapat diskakmat sewaktuwaktu dan Maryamah tidak menyadarinya. Pengumpamaan kondisi Maryamah ini sama dengan seekor capung yang tidak sadar akan disambar burung prenjak untuk dijadikan makanannya.

32. Berikutnya, ibarat papan catur itu $k u d a$, tali kekangnya digenggam Matarom. (Hirata:298).

Papan catur adalah sebuah permainan yang dapat dikendalikan oleh seseorang yang sangat ahli memainkannya. Seseorang yang sangat ahli dapat menyetir lawan sesuai dengan kehendaknya. Oleh sebab itu, mengibaratkan permainan catur dengan mengendalikan seekor kuda terasa sangat tepat.

\section{Simpulan}

Gaya bahasa perumpamaan yang terdapat dalam novel Cinta di dalam Gelas karya Andrea Hirata cukup banyak dan beragam. Gaya bahasa tersebut menggunakan kata-kata pembanding, yaitu seperti, bak, dan ibarat. Jumlah pemakaian kata pembanding kata seperti yang dijadikan sampel penelitian adalah 22 buah yang terdapat dalam 22 gaya bahasa perumpamaan. Jumlah pemakaian kata pembanding bak yang dijadikan sampel penelitian adalah 7 buah yang terdapat dalam 7 gaya bahasa perumpamaan. Jumlah pemakaian kata pembanding macam yang dijadikan sampel penelitian adalah 2 kata yang terdapat dalam 2 gaya bahasa perumpamaan dan jumlah pemakaian kata pembanding ibarat yang dijadikan sampel penelitian adalah 1 kata yang terdapat dalam 1 gaya bahasa perumpamaan.

Gaya bahasa digunakan oleh pengarang untuk menciptakan asosiasi tertentu yangmakin memperkuat nilai kesastraan dari karya sastra itu sendiri. Oleh sebab itu, pengarang yang baik tentu akan banyak 
menggunakan perangkat gaya bahasa dalam menciptakan karya sastranya.

Pemakaian gaya bahasa perumpamaan dalam sebuah novel akan menciptakan maknamakna yang bergantung pada konteks kalimat perumpamaan itu sendiri. Dengan demikian, penguraian makna yang ditimbulkan oleh pemakaian gaya bahasa perumpamaan dalam novel Cinta di dalam Gelas ini menjadi sebuah analisis yang makin memperjelas makna dari novel itu sendiri.

\section{Daftar Pustaka}

Achmadi. 1988. Materi Dasar Pengajaran Komposisi Bahasa Indonesia. Jakarta Depdikbud.

Aminuddin. 2001. Kerangka Pemahaman Sastra Modern. Malang: PPS UM.

Endraswara, Suwardi. 2011. Metodologi Penelitian Sastra: Epistemologi, Model, Teori, dan Aplikasi. Yogyakarta: FBS Universitas Negeri Yogyakarta.

Hendy, Zaidan. 1993. Kasusastraan Indonesia Warisan yang Perlu Diwariskan 2. Bandung: Angkasa.

Hirata, Andrea. 2011. Cinta di dalam Gelas. Jakarta: Bentang Pustaka.

Minderop, Albertine. 2005. Metode Karakteristik Telaah Fiksi. Jakarta: Yayasan Pustaka Obor Indonesia.

Moeliono, Anton. M. 1989. Kembara Bahasa. Jakarta: PT Gramedia.

Moleong, Lexy. J. 2007. Metode Penelitian Kualitatif. Bandung: Remaja Rosda Karya.

Nurgiyantoro, Burhan. 2002. Teori Pengkajian Fiksi. Yogyakarta: Gadjah Mada University Press.

Pradopo, Rachmad Djoko. 2005. Beberapa Teori Sastra, Metode, Kritik, dan Penerapannya. Yogyakarta: Pustaka Pelajar.

Pusat Bahasa Depdikbud. 2013. Kamus Besar Bahasa Indonesia: Cet. Ketujuh Edisi Keempat. Jakarta: Gramedia Pustaka Utama.

Semi, Atar. M. 1993. Anatomi sastra. Padang: Angkasa Raya.

Sudjiman, Panuti. 1998. Bunga Rampai Stilistika. Jakarta: Pustaka Jaya.
Tarigan, Henry Guntur. 2011. Pengajaran Semantik. Bandung: Angkasa.

Zulfahnur dkk. 1996. Teori Sastra. Jakarta: Depdikbud Argesindo.

Zainuddin. 1991. Materi Pokok Bahasa dan Sastra Indonesia. Jakarta: Grasindo. 